\title{
Developing Teaching Kit on the Use of Micro-Hydro Generator in Remote Area
}

\author{
Desak Made Megawati \\ SMP Negeri 4 Masamba. Kappuna, North Luwu Regency, South Sulawesi 92961, Indonesia \\ Email: desak.megawati@yahoo.co.id
}

Received: 4 April 2016; Revised:8 April 2017; Accepted: 2 June 2017

\begin{abstract}
The study aimed at: (1) identifying the criteria of teaching kit feasibility for the advantages of micro-hydro generator in remote area; and (2) identifying the effectiveness of teaching kit implementation on the use of micro-hydro generator in remote area in order to improve the students' concept mastery on SMP Negeri 1 Rampi South Sulawesi. The study was a research and development that adapted the 4D model, which consisted of define, design, develop, and disseminate. The teaching kit that had been developed was a syllabus, lesson plans, student's worksheet, and assessment instrument. For the data gathering, the researcher implemented the non-test technique, in the form of product validation sheet, student's worksheet readability questionnaire sheet, teaching implementation sheet, and test technique, in the form of concept mastery test item sheet. The results of the study show that: (1) the teaching kit on the use of micro-hydro generator in remote area that has been developed falls into the "Very Good" category for syllabus, lesson plan, and student's worksheet; and (2) the implementation of the teaching kit on the use of micro-hydro generator in remote area has been effective to improve the students' concept mastery in SMP Negeri 1 Rampi South Sulawesi.
\end{abstract}

Keywords: teaching kit, micro-hydro generator, concept mastery

How to Cite: Megawati, D. (2017). Developing teaching kit on the use of micro-hydro generator in remote area. Jurnal Inovasi Pendidikan IPA, 3(1), 22-29. doi:http://dx.doi.org/10.21831/jipi.v3i1.8357

Permalink/DOI: http://dx.doi.org/10.21831/jipi.v3i1.8357

\section{INTRODUCTION}

Every citizen has the right to attain teaching and education whether the citizens live in the city, in the urban area, or even in the remote area. This matter is formulated in the 1945 Constitution Article 31 Verse (1). The government also has the responsibility to hold a national education system that might improve piety and faithfulness in order to enlighten the life of the nation according to the mandate of 1945 Constitution Article 31 Verse (1).

In order to implement the education or the learning activities in the school, teaching kit is the main aspect that a teacher prepares in conducting the learning process. Teaching kit is a tool or equipment for performing a process that might enable teachers and students to do the learning activities. Teaching kit is designed as a support so that learning process might run well (Prasetyo, 2011).

Every teacher in any educational unit has the responsibility to design complete and systematic teaching kit in order that the learning process might proceed with interaction, inspi- ration, enjoyment, and full of challenges. Such learning process will motivate the students to participate actively and will provide sufficient space for the students' initiatives, creativity, and independence according to their talents, interests, and physical and psychological development (Devi, Sofiraeni, \& Khairuddin, 2009, p. 1).

Based on the results of field observation, the researcher found that in general the teachers who have been teaching in Rampi have not been able to design their own teaching kit. Instead, the teachers make use of teaching kit that they have attained from the schools that are located in the city as part of administrative requirements. Certainly, this situation is not in accordance to that in Rampi. Moreover, Rampi is a remote area which condition is certainly different than the city.

The District of Rampi is a remote area the belongs to the Regency of North Luwu. One of the criteria for being considered as a remote area is having difficult and expensive transportation access due to unavailable highway access and 


\section{Jurnal Inovasi Pendidikan IPA, 3 (1), 2017 - 23}

Desak Made Megawati

weather dependency. As a result, the only possible way to get to the district is by foot. This district has extraordinary difficulties and natural challenges and, in the same time, this district has very limited acess to general facilities, educational facilities, health facilities, electricity, information and communication facilities and clean water facilities. This situation might be considered completing the criteria of being considered as a remote area. In general, the criteria of being considered as a remote area as follows: (1) the area is difficult to access due to the lack and the limited public transportation facilities, either the land, the sea, or the air one; and (2) the social and economic facilities are unavailable or might be limited (Asriati, 2013).

Law Number 20 Year 2003 Article 36 states that curriculum development should be based on the principle of deverification in accordance to the regional potentials and the students' characteristics. Therefore, in developing the teaching kit in the school the teachers should benefit the existing regional potentials of local potentials. The local potentials refer to the potentials of specific resources that have been possessed by a region. These potentials should be benefitted in order to support the educational decentralization. The local potentials that cover natural, human, and technological resources might be developed in order to achieve national independence (Sarah \& Maryono, 2014).

Natural resources refer to the natural assets that a region has possessed in order to provide society welfare (Napitupulu, 2009). Natural resources are potentials that have been possessed in the land, the sea, and the sky and these natural resources might be empowered to serve various needs (Asmani, 2012, p. 33). The natural resources that exist in the District of Rampi refer to the local potentials that might be benefitted in the form of micro-hydro generator. Micro-hydro generator is a small-scale generator that makes use of water such as irrigation channel, river, or natural waterfall as its driving force. This micro-hydro generator makes use of the water level and flow (Gunawan, Oktafeni, \& Khabzli, 2014).

Micro-hydro generator works as follows. First, the river stream is dammed in order to attain water flow and water level. Second, the water flow and level that have been attained is channeled through a carriage to the conditioning pool. The conditioning pool is connected to the rapidity pipe and the rapidity pipe is installed under the turbine. Third, the turbine will spin after it has been given water pressure and the spin is used for empowering the generator (Sukamta \& Kusmantoro, 2015).

Based on 2006 Curriculum for Grade VIII Junior High School, in the Natural Science subject there are competence standards that might benefit the existing local potentials. However, based on the results of field observation in the junior high schools located in the District of Rampi there have not been any teachers who benefit the local potentials in the learning process especially for Natural Science subject. The learning method that has been implemented by the teachers is limited on lecturing and textbook copying. The reaso is that the junior high schools in this district have limited facilities. Therefore, the use of micro-hydro generator in the Natural Science learning activities might be directed to encourage the students to attain direct experience according to their daily life so that the learning process will be more meaningful and the knowledge might be detained longer in the students' mind.

One of the most important objectives in the Natural Science subject is teaching students how to be involved in investigation. In other words, students should integrate their skills, knowledge, and attitudes to develop better understanding toward concepts (Zeidan \& Jayosi, 2014). Concept mastery is an understanding toward the abstraction of events, objects, or phenomena that have certain attributes or characteristics. The most important objective in a learning process is assisting the concept implantation into the students' mind instead of merely memorizing separated facts. Concept mastery might be improved when a teacher explores a learning topic through an appropriate and in-depth manner and provides interesting examples according to the concept under study. Concept is the basis of constructing the thinking process (Santrock, 2010, p. 295).

Carin \& Sund (1989, p. 12) stated that a concept is an idea generalized from particular and relevant experiences. This statement implies that a concept is a general idea that results from relevant experiences. Similarly, Rosser (Dahar, 2012, p. 63) stated that concept is an abstraction that represents a class of objects, occurrences, or activities which have similar attributes. One of the difficulties in defining concept is that each person has and defines his or her own concepts according to the stimuli that the person experiences. According to Ausubel (Dahar, 2012, p. $64)$, there are two ways that might be used for 


\section{Jurnal Inovasi Pendidikan IPA, 3 (1), 2017 - 24}

Desak Made Megawati

attaining a concept. The first way is defining a concept from the patterns or the regulations that have been applied and that have been common inductively. On the other hand, the second way is assimilating a concept; in this assimilation, the concept has been attained deductively. The second way emphasizes the concept introduction to the students before the concept is assimilated into the attributes.

Santrock (2010) stated that the students' concept mastery has been influenced by psychological factors, namely intelligence, attention, attraction, attitude, motivation, maturity, and fatigue. Furthermore, the students' concept mastery is also influenced by the learning strategies (Putra, Sudargo, Redjeki, \& Adianto, 2014).

Nurhadi et al. (2016) stated that the weak concept mastery has been caused by many factors such as the learning methods that have not been fit into the material characteristics and the teacher-centered classical learning activities. McBridge (2014) also argued that many students have only been memorizing concepts, been taking notes on what the teachers explain, been passive, been seldom in using knowledge as the basis of their learning plan (Nurhadi et al., 2016).

\section{METHOD}

This study was a research and development that adopted the 4D model by Thiagarajan, Semmel, \& Semmel (1974, pp. 6-9). The steps in this study consisted of define, design, develop, and disseminate.

The study took place from December 2015-February 2016 during 2015/2016 Academic Year. Then, the study was conducted in SMP Negeri 1 Rampi, the Regency of Northern Luwu, in order to develop the teaching kit on the use of micro-hydro generator in the remote area.

The subjects in this study were VIII Grade students from 3 classes. 9 VIII Grade students from SMP Negeri 3 Rampi served as the subjects in the limited experiment and 18 VIII A Grade students from SMP Negeri 1 Rampi were assigned into the experimental group. On the other hand, 18 VIII B Grade students form SMP Negeri 1 Rampi were assigned into the control group. Moreover, there were also IX Grade students who had been selected as the subjects for empirical test item-validity test.

In the Define step, the researcher performed needs analysis. The needs analysis included the analysis toward the Natural Science subject problems that the school had, the analysis toward the curriculum in relation to the competence standards and the basic competencies, the analysis toward the concept, and the design of concept map.

In the Design step, the researcher drafted the design, the form, and the substances of the teaching kit. In the same time, the researcher also designed the media selection instrument, the format selectiom, and the initial draft of the design that would be developed. The product that had been developed included syllabus, lesson plan, student's worksheet, and assessment instrument. The results in this step were syllabus development guideline, lesson plan, student's worksheet, and assessment instrument.

In the Develop step, the researcher performed the product development, the product validation, and the limited experiment. The validation was conducted by the experts and the practitioners. After the product had been validated, the researcher performed the first revision. Next, the researcher implemented the product in a limited group, namely in a group that consisted of 9 students who had been selected from three categories: students with high capabilities, students with moderate capabilities, and students with low capabilities. After the experiment had been done, the researcher performed the second revision before the product would be tested further in the field experiment. The design for the field experiment referred to the pretest and posttest design. The field experiment was conducted before and after the learning process for each group had been done. However, before conducting the field experiment, the researcher performed preliminary observation before the treatment had been applied and another observation during the treatment in order to measure the skill process. The pretest and the posttest was conducted in order to measure the students' concept mastery. The design might be viewed in Table 1 . 
Jurnal Inovasi Pendidikan IPA, 3 (1), 2017 - 25

Desak Made Megawati

Table 1. Pretest and Posttest Design that Had been Adopted from Creswell (2012, p. 301)

\begin{tabular}{cclcr}
\hline Group & Pretest & Treatment & Posttest \\
\hline Experimental & P1 & $\begin{array}{l}\text { Treatment in the form of teaching kit on the use of micro-hydro generator in } \\
\text { remote area }\end{array}$ & P2 \\
Control & P2 & Treatment in the form of teaching that has been generally applied in the school & P2 \\
\hline
\end{tabular}
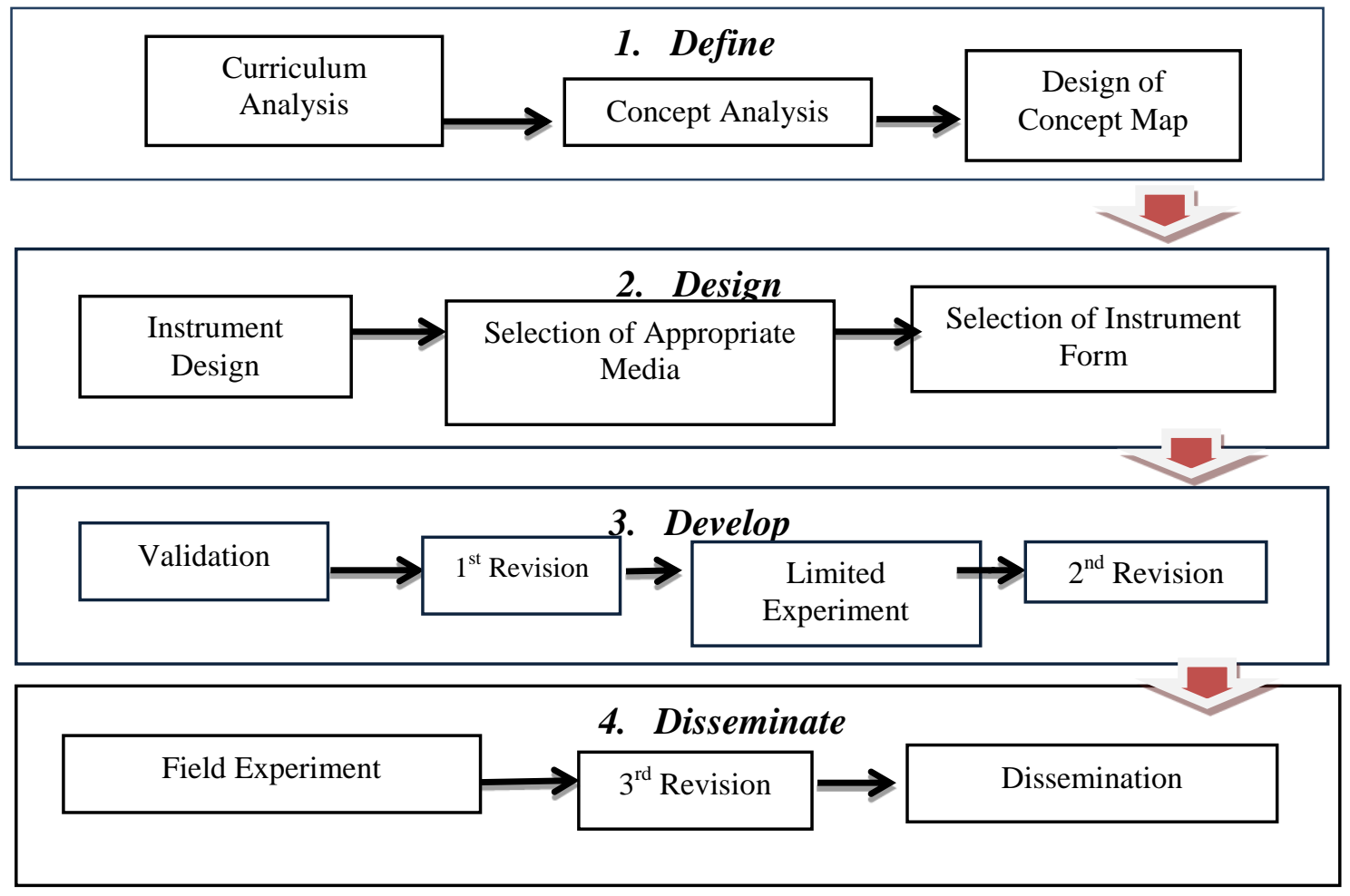

Figure 1. 4D Research and Development Model

In the Disseminate step, the researcher implemented the teaching kit that had been adopted to the wider scale, namely into the experimental group and the control group that had been selected for the sake of comparison. The objective was testing the effectiveness on the use of the teaching kit in the learning process that took place in the classroom. After the experiment for both groups had been done, the researcher performed revision and the teaching kit would be ready for publication in the wider scale. For example, the teaching kit might be printed and be used among the Subject Teachers Group (MGMP). In sum, the steps in conducting this research and development might be viewed in Figure 1.

\section{Data, Instrument, and Data Gathering Technique}

The data in this study were gathered through observation, questionnaire distribution, and test. The observation technique that had been implemented was observation sheet in order to review the Natural Science subject process on the needs analysis and the lesson plan implementation. The questionnaire distribution technique was implemented as well in order to measure the students' response toward the student's worksheet readability, while the validation sheet was implemented in order to validate the teaching kit on the use of microhydro generator in the remote area. Last but not the least, the test technique in the form of multiple choice test items was implemented in order to measure the students' concept mastery.

\section{Data Analysis Technique}

The data analysis techniques that had been implemented in order to attain the expected results were classified as follows: product feasibility, lesson plan implementation, student's worksheet readability analysis, students' concept mastery improvement analysis, and teaching kit effectiveness analysis. The product feasibility analysis was conducted qualitatively and quantitatively. The qualitative results were the experts' critics and suggestions. Especially for the student's worksheet, the researcher also paid 
Jurnal Inovasi Pendidikan IPA, 3 (1), 2017 - 26

Desak Made Megawati

attention to the VIII Grade students' readability. On the other hand, the quantitative results were attained from the assessment toward the syllabus, the lesson plan, the student's worksheet, and the observation sheet in the form of experts' score that had been provided on the validation sheet. These scores then were converted into 4-point Likert scale that referred to the National Department of Education (Departemen Pendidikan Nasional, 2010, p. 60). The conversion was presented in Table 2 as follows.

Table 2. Product Feasibility Category

\begin{tabular}{rcc}
\hline No. & Score Interval & Criteria \\
\hline 1. & $\mathrm{Mi}+1,5 \mathrm{SDi}<\overline{\mathrm{X}} \leq \mathrm{Mi}+3,0 \mathrm{SDi}$ & Very Good \\
2. & $\mathrm{Mi}+0 \mathrm{SDi}<\overline{\mathrm{X}} \leq \mathrm{Mi}+1,5 \mathrm{SDi}$ & Good \\
3. & $\mathrm{Mi}-1,5 \mathrm{SDi}<\overline{\mathrm{X}} \leq \mathrm{Mi}+0 \mathrm{SDi}$ & Moderate \\
4. & $\mathrm{Mi}-3 \mathrm{SDi}<\overline{\mathrm{X}} \leq \mathrm{Mi}-1,5 \mathrm{SDi}$ & Poor \\
\hline
\end{tabular}

Note:

MI = Ideal Mean Score

$=\frac{1}{2}($ maximum score + minimum score $)$

SDI $=$ Ideal Standard Deviation

$=\frac{1}{6}($ maximum score - minimum score $)$

$\bar{x}=$ Average score of empirical data

The analysis of lesson plan implementation would be converted into 5-point Likert scale in Table 3 as follows.

Table 3. Lesson Plan Implementation Category

\begin{tabular}{ccc}
\hline No. & Score Range $(\boldsymbol{\%})$ & Criteria \\
\hline 1. & $80-100$ & Very Good \\
2. & $70-79$ & Good \\
3. & $60-69$ & Moderate \\
4. & $45-59$ & Poor \\
5. & $<44$ & Very Poor \\
\hline
\end{tabular}

The analysis of concept mastery was measured by operating the following formula:

Score $=\frac{\text { Achievement Score }}{\text { Maximum Score }} \times 100$

The students' concept mastery improvement in overall would be analyzed through the following normalized gain formula:

$<g>=\frac{\%<\text { posttest }>-\%<\text { pretest }>}{100-\%<\text { pretest }>}$

Note:

$\langle\mathrm{g}\rangle \quad=$ Average normalized gain score

$\%<$ posttest $>=$ Average percentage of the students' posttest score

$\%<$ pretest $>=$ Average percentage of the students' pretest score
Table 4. Gain Normalized Average Score Category

\begin{tabular}{ccc}
\hline No. & $\langle\mathrm{g}\rangle$ score & Category \\
\hline 1. & $\langle\mathrm{~g}\rangle>0.7$ & High \\
2. & $0.3 \leq<\mathrm{g}>\leq 0.7$ & Moderate \\
3. & $\langle\mathrm{~g}\rangle<0.3$ & Low \\
\hline
\end{tabular}

(Hake, 1999)

The effectiveness of teaching kit implementation on the field experiment was analyzed based on the normalized gain average scores and the t-test.

\section{RESULTS AND DISCUSSIONS}

This study generates a final product in the form of teaching kit on the use of micro-hydro generator in the remote area that belongs to the Regency of Northern Luwu. The teaching kit that has been developed includes syllabus, lesson plan, student's worksheet, and concept mastery assessment instrument on the learning materials of energy for the VIII Grade of Junior High School in Semester 2.

The feasibility of the teaching kit on the use of micro-hydro generator could be identified after the researcher had analyzed the data that have been attained from the experts. The experts consisted of two expert lecturers, two colleagues, and two practitioners. The product validation was conducted by the experts through the validation sheet. The validation sheet contained several aspects for each component of teaching kit on the use of micro-hydro generator in remote area. The aspect assessment consisted of 4 scales.

The syllabus that has been developed is in accordance to Educational Unit Level Curriculum (Kurikulum KTSP) and in the syllabus there is the use of micro-hydro generator on the Energy learning materials for VIII Grade of Junior High School. The components of the syllabus consist of school identity, subject, grade/semester, competence standards, basic competencies, compulsory materials, indicators of competence achievement, assessment, time allocation, and learning sources.

The lesson plan that has been developed is in accordance to the Educational Unit Level Curriculum and the components of this lesson plan consist of school identity (educational unit, subject, grade/semester, time allocation, compulsory materials, and meetings), competence standards, basic competencies, indicators of achievement, learning objectives, learning materials, learning methods, learning activities, assessment, and learning sources. The lesson 
plan that has been developed is designed for three meetings and the time allocation is 6 learning periods. The first meeting is designed to study energy forms, the second meeting is designed to study the change of energy form, and the third meeting is designed to study mechanical energy. Each meeting lasts for two learning periods.

The student's worksheet that has been developed is in accordance to the planning that has been formulated in the lesson plan. The student's worksheet is designed for 3 meetings. The objective of the first meeting is describing energy forms, the objective of the second meeting is describing the change of energy forms, and the objective of the third meeting is describing mechanical energy. The instrument of the students' concept mastery assessment is the concept mastery test. The students' concept mastery test consists of 20 test items that have been validated by the experts; if the test item is not valid, then the experts will provide notifications for revision. The concept mastery test is administered before and after the treatment and the treatment itself is the teaching kit on the use of micro-hydro generator in remote area. The scores on the results of product assessment is elaborated in Table 5.

Table 5. The Results of Analysis toward the Expert Lecturers' Validation

\begin{tabular}{clcc}
\hline No. & Teaching Kit & $\begin{array}{c}\text { Average } \\
\text { Score }\end{array}$ & Category \\
\hline 1. & Syllabus & 3.50 & Very Good \\
2. & Lesson Plan & 3.88 & Very Good \\
3. & Student's Worksheet & 3.38 & Very Good \\
\hline
\end{tabular}

Table 6. The Results of Analysis toward the Practitioners' Validation

\begin{tabular}{clcc}
\hline No. & Teaching Kit & $\begin{array}{c}\text { Average } \\
\text { Score }\end{array}$ & Category \\
\hline 1. & Syllabus & 3.81 & Very Good \\
2. & Lesson Plan & 3.60 & Very Good \\
3. & Student's Worksheet & 3.63 & Very Good \\
\hline
\end{tabular}

Table 7. The Results of Analysis toward the Colleagues' Validation

\begin{tabular}{llcl}
\hline No. & \multicolumn{1}{c}{ Teaching Kit } & $\begin{array}{c}\text { Average } \\
\text { Score }\end{array}$ & Category \\
\hline 1. & Syllabus & 3.75 & Very Good \\
2. & Lesson Plan & 3.65 & Very Good \\
3. & Student's Worksheet & 3.50 & Very Good \\
\hline
\end{tabular}

Table 8. The Results of Analysis toward Combined Validation

\begin{tabular}{clcc}
\hline No. & \multicolumn{1}{c}{ Teaching Kit } & $\begin{array}{c}\text { Average } \\
\text { Score }\end{array}$ & Category \\
\hline 1. & Syllabus & 3.75 & Very Good \\
2. & Lesson Plan & 3.68 & Very Good \\
3. & Student's Worksheet & 3.50 & Very Good \\
\hline
\end{tabular}

From the results of the analysis and based on the experts' validation, the researcher found that the teaching kit that consisted of syllabus, lesson plan, and student's worksheet had been feasible for implementation; the suggestions and revisions that had been provided by the experts confirmed that teaching kit had fallen into the "Very Good" category. The experts also performed validity test in the analysis of product (concept mastery test items) feasibility; if the product was not feasible, then the experts would provide notification for revisions. Before being implemented in the experimental group, the researcher would perform an empirical test toward the product. The results of this empirical test would be analyzed by means of Microsoft Excel in order to identify the item validation and the concept mastery instrument reliability based on the Product Moment Correlation toward the 20 multiple choice test items. The interpretation toward the correlation coefficient value was performed by comparing the $r_{x y}$ value and the critical value $(0.300)$. An instrument would be considered valid if $r_{x y} \geq 0.300$ (Widoyoko, 2012, p.149) and the results of the analysis showed that 20 test items had been considered valid with index of reliability that had been equal to 0.703 . The index of reliability that had been attained as bigger than 0.636 and, as a result, the test items considered reliable.

In the limited experiment, the analysis toward the percentage of lesson plan implementation for the first meeting showed that the lesson plan had been $81.38 \%$ implemented. Then, the analysis toward the percentage of lesson plan implementation for the second showed that the lesson plan had been $75.00 \%$ implemented. Next, the analysis toward the percentage of lesson plan implementation for the third meeting showed that the lesson plan had been $87.50 \%$ implemented, which belonged to the "Very Good" category. In terms of material presentation and layout, the average score of the student's worksheet readability was equal to 3.47 and belonged to the "Very Good" category.

In the field experiment, the researcher implemented the teaching kit to the experimental group. The analysis toward the percentage of 
lesson plan implementation for the first meeting showed that the lesson plan had been $93.75 \%$ implemented. Then, the analysis toward the percentage of lesson plan implementation for the second meeting showed that the lesson plan had been $93.75 \%$ implemented. Next, the analysis toward the percentage of lesson plan implementation for the third meeting showed that the lesson plan had been $93.75 \%$ implemented as well. Therefore, the percentage of lesson plan implementation fell into the "Very Good" category.

The implementation effectiveness for the teaching kit on the use of micro-hydro generator in remote area was identified through the field experiment. Based on the analysis toward the results of field experiment by means of normalized gain, the researcher found that the implementation of the teaching kit on the use of micro-hydro generator in remote area that had been developed could improve the students' concept mastery. The results of analysis toward the average normalized gain score $(\langle\mathrm{g}\rangle)$ showed the improvement on the students' concept mastery. The overall results might be seen in Table 8.

Table 8 . The Category of Improvement on the Field Experiment

\begin{tabular}{|c|c|c|}
\hline \multirow[t]{2}{*}{ Response Variable } & $\begin{array}{c}\text { Experimental } \\
\text { Group }\end{array}$ & $\begin{array}{l}\text { Control } \\
\text { Group }\end{array}$ \\
\hline & $\langle$ g $\rangle$ Category & $\langle$ g $\rangle$ Category \\
\hline Concept Mastery & 0.49 Moderate & 0.32 Moderate \\
\hline
\end{tabular}

From Table 8, it was apparent that the concept mastery improvement of the students in the experimental group that had been measured by the average normalized gain score $(\langle\mathrm{g}\rangle)$ had been equal to 0.49 and had fallen into the "Moderate" category; on the other hand, the concept mastery improvement of the students in the control group that had been measured by the average normalized gain score $(\langle\mathrm{g}\rangle)$ had been equal to 0.32 and had fallen into the "Moderate" category.

Based on a series of analysis test (homogeneity test, normality test, and t-test) toward the posttest score, the researcher found that the significance value had been 0.00 ( $\mathrm{Sig}<0.05$ ) which implied that $\mathrm{H}_{0}$ had been rejected. Thereby, there had been differences between the concept mastery posttest average scores between the students in the experimental group and those in the control group. This finding implied that the application of the teaching kit on the use of micro-hydro generator in remote area could provide direct experience to the students according to their daily life. As a result, the learning process would not be boring and the students would be more active. Thus, the concept mastery could be retained longer and the students would not be merely memorizing the concepts.

\section{CONCLUSIONS}

Based on the results and discussion, the researcher may conclude that: (1) the teaching kit regarding Energy learning materials on the use of micro-hydro generator in remote area that consists of syllabus, lesson plan, and student's worksheet falls into the "Very Good" category based on the assessment by the experts, the colleagues, and the practitioners and also the concept mastery test shows valid and reliable value so that the teaching kit is feasible for implementation; and (2) the application of the teaching regarding Energy learning materials on the use of micro-hydro generator in remote area that has been developed is effective to improve the students' concept mastery.

\section{REFERENCES}

Asmani, J. M. (2012). Pendidikan berbasis keunggulan lokal. Yogyakarta: Diva Press.

Asriati, N. (2013). Pengembangan Model Pendidikan Sekolah Kebangsaan "di daerah terpencil, tertinggal, terluar dan perbatasan Kalimatan Barat-Serawak Malaysia. In Seminar Nasional 2013 (pp. 665-674). Yogyakarta: Universitas Negeri Yogyakarta.

Carin, A. A., \& Sund, R. B. (1989). Teaching science through discovery. London: Merrill.

Creswell, J. W. (2012). Educational research: planning, conducting, and evaluating quantitative and qualitative research. Boston: Pearson. Retrieved from https://www.pearson.com/us/highereducation/product/Creswell-EducationalResearch-Planning-Conducting-andEvaluating-Quantitative-and-QualitativeResearch-4thEdition/9780131367395.html

Dahar, R. W. (2012). Teori-teori belajar \&amp; pembelajaran. Jakarta: Erlangga. http://doi.org/2012

Departemen Pendidikan Nasional. (2010). Juknis penyusunan perangkat penilaian psikomotor di SMA. Jakarta: Direktorat 
Pembinaan SMA, Departemen Pendidikan Nasional.

Devi, P. K., Sofiraeni, R., \& Khairuddin, K. (2009). Pengembangan perangkat pembelajaran untuk guru SMP. Bandung: Pusat Pengembangan dan Pemberdayaan Pendidik dan Tenaga Kependidikan Ilmu Pengetahuan Alam. Retrieved from https://mgmpmatsatapmalang.files.wordpr ess.com/2012/07/pengembanganperangka tsmp.pdf

Gunawan, A., Oktafeni, A., \& Khabzli, W. (2014). Pemantauan pembangkit listrik tenaga mikrohidro (PLTMH). Jurnal Rekayasa Elektrika, 10(4), 201-206. http://doi.org/10.17529/jre.v10i4.1113

Hake, R. R. (1999). Analyzing change/Gain scores. Retrieved from http://www.physics.indiana.edu/ sdi/Anal yzingChange-Gain.pdf

Napitupulu, J. (2009). Pembangkit listrik tenaga mini hidro (PLTM) dalam pengelolaan energi hijau. Jurnal Darma Agung, 2125.

Nurhadi, N., Lukman, L., Abas, R., Erni, E., Yuliana, Y., \& Hamrin, H. (2016). Implementation of inquiry based learning to improve understanding the concept of electric dynamic and creative thinking skills (An empirical study in class ix junior high school students state 4 Kendari). International Journal of Science and Research (IJSR) ISSN (Online Index Copernicus Value Impact Factor, 5(3), 2319-7064. Retrieved from https://www.ijsr.net/archive/v5i3/NOV16 1532.pdf

Prasetyo, Z. K. (2011). Pengembangan perangkat pembelajaran sains terpadu untuk meningkatkan kognitif, keterampilan proses, kreativitas serta menerapkan konsep. Yogyakarta.

Putra, R. A., Sudargo, F., Redjeki, S., \& Adianto, A. (2014). The analysis of concepts mastery and critical thinking skills on invertebrate zoology course. International Journal of Science and Research, 3(3). Retrieved from https://www.ijsr.net/archive/v3i3/MDIw MTMxMTk2.pdf

Santrock, J. (2010). Educational Psychology. Handbook of Educational Psychology. http://doi.org/10.1146/annurev.ps.05.0201 54.002041

Sarah, S., \& Maryono, M. (2014). Keefektivan pembelajaran berbasis potensi lokal dalam pembelajaran fisika SMA dalam meningkatkan living values siswa. JURNAL PENDIDIKAN SAINS (JPS), 2(1), 36-42. Retrieved from http://jurnal.unimus.ac.id/index.php/JPKI MIA/article/view/1382

Sukamta, S., \& Kusmantoro, A. (2015). Perencanaan pembangkit listrik tenaga mikro hidro (PLTMH) Jantur Tabalas Kalimantan Timur. Jurnal Teknik Elektro, 5(2). Retrieved from https://journal.unnes.ac.id/nju/index.php/jt e/article/view/3555

Thiagarajan, S., Semmel, D. S., \& Semmel, M. I. (1974). Instructional development for training teachers of exceptional children: A sourcebook. Blomington: may be ordered from the Council for Exceptional Children.

Zeidan, A. H., \& Jayosi, M. R. (2014). Science process skills and attitudes toward science among palestinian secondary school students. World Journal of Education, $5(1)$, http://doi.org/10.5430/wje.v5n1p13 